Tohoku J. exp. Med., 1978, 126, 399-400

Short Report

\title{
Low Incubation Temperature Favors Detection of Depolarization-Induced Coated Vesicles in Motor Axon Endings in Frog Nerve-Muscle Preparations
}

\author{
Ken Kadota and Tomoko Kadota \\ Departments of Pharmacology and Anatomy, Osaka University \\ Medical School, Kita-ku, Osaka 530
}

\begin{abstract}
Kadota, K. and Kadota, T. Low Incubation Temperature Favors Detection of Depolarization-Induced Coated Vesicles in Motor Axon Endings in Frog NerveMuscle Preparations. Tohoku J. exp. Med., 1978, 126 (4), 399-400 — Depolarization-induced coated vesicles were detected in motor axon endings in frog nervemuscle preparations stimulated at $10^{\circ} \mathrm{C}$ but hardly in those activated at $25^{\circ} \mathrm{C}$ frog neuromuscular synapse; low temperature; coated vesicles
\end{abstract}

While studying morphological changes in motor axon terminals following repetitive excitation, Heuser and Reese (1973) observed formation of coated vesicles (CV). They interpreted $\mathrm{CV}$ as an intermediate to re-form synaptic vesicles (SV) that were depleted during excitation. Ceccarelli et al. (1972), however, have a different view; since they did not observe $\mathrm{CV}$, they maintained that SV should be re-formed directly from the axon terminal membrane at the point of exocytosis. Above-mentioned two groups of workers conducted their experiments with different temperatures; Heuser and Reese (1973) incubated preparations at $10^{\circ} \mathrm{C}$, whereas Ceccarelli et al. (1972) did so at a room temperature of $22-23^{\circ} \mathrm{C}$. From this we hypothesized that low temperature would be favorable for the detection of depolarization-induced CV. We tested it with the cat superior cervical sympathetic ganglion and found it to be true (Kadota and Kadota 1978). A further test of the hypothesis was made in the present experiment with nerve-muscle preparations.

Nerve-muscle preparations were obtained from cutaneous pectoris and sartorius muscles of Rana nigromaculata. They were incubated in Ringer solution containing d-tubocurarine chloride $(3-10 \mu \mathrm{g} / \mathrm{ml})$ and glucose $(3 \mathrm{mM})$ at $10^{\circ} \mathrm{C}$ or $25^{\circ} \mathrm{C}$. Motor nerves were stimulated at $10 \mathrm{~Hz}$ for $15 \mathrm{~min}$ with rectangular pulses of $0.1 \mathrm{msec}$ and $5 \mathrm{~V}$. After stimulation the materials were treated for electron microscopy as described in our previous paper.

Fig. 1 shows photographs obtained from cutaneus pectoris muscle preparations. Fig. la demonstrates a non-stimulated control material incubated at $25^{\circ} \mathrm{C}$. SV are seen seattered throughout cytoplasm together with mitochondria. Essentially similar findings were obtained with a control material maintained at $10^{\circ} \mathrm{C}$. Effects of stimulation of motor nerves are shown in Fig. $1 \mathrm{~b}$ and $\mathrm{c}$, for which preparations were incubated at $10^{\circ} \mathrm{C}$ and $25^{\circ} \mathrm{C}$, respectively. In both cases, SV were reduced in number, especially at active zones where the presynaptic membrane faces junctional folds. Mitochondria were swollen. The difference between the two cases is that coated pits and $C V$ are seen in materials stimulated at $10^{\circ} \mathrm{C}$ (Fig. 1b), but they are hardly seen at $25^{\circ} \mathrm{C}$ (Fig. 1c).

The present results indicate that as shown with the cat superior cervical ganglion previously, low incubation temperature is an important factor for the appearance of depolarization-induced $\mathrm{CV}$ in frog motor nerve terminals as well. Heuser and Reese (1973)

Received for publication, June 6, 1978. 

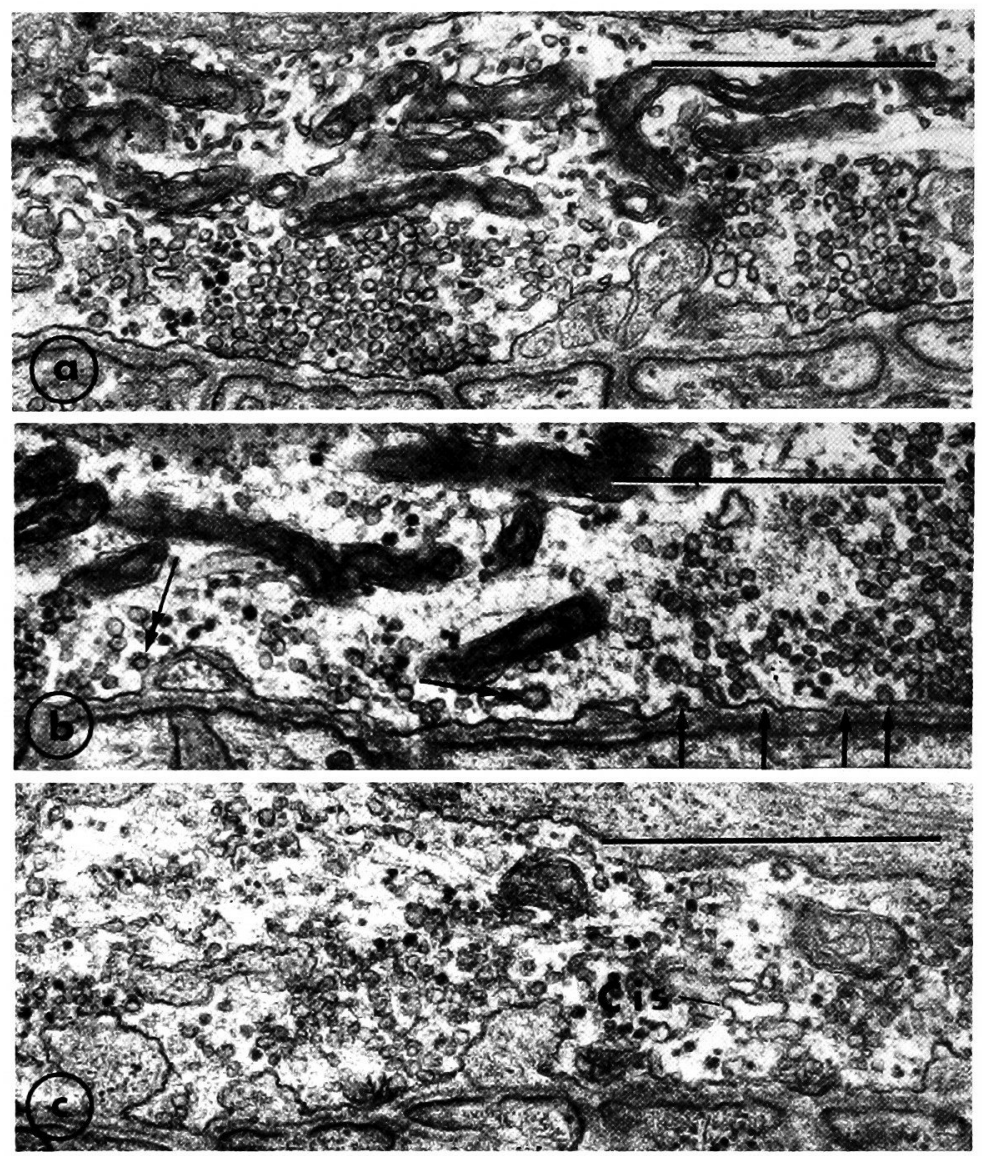

Fig. 1. Neuromuscular junctions of frog cutaneous pectoris muscle. a: Non-stimulated control at $25^{\circ} \mathrm{C}$. b: Stimulated at $10^{\circ} \mathrm{C} . \quad$ c: Activated at $25^{\circ} \mathrm{C}$. Arrows, coated pits; Double-headed arrows, coated vesicles (CV); Cis, intraterminal cistern. Bars equal $1 \mu \mathrm{m}$.

succeeded in observing depolarization-induced $\mathrm{CV}$ by maintaining preparations at low temperature, but simultaneously they used a long-time block stain with uranyl acetate. The latter procedure may also be favorable for detecting depolarization-induced CV.

\section{References}

1) Ceccarelli, E., Hurlbut, W.P. \& Mauro, A. (1972) Depletion of vesicles from frog neuromuscular junctions by prolonged tetanic stimulation. J. Cell Biol., 54, 30-38.

2) Heuser, J.E. \& Reese, T.S. (1973) Evidence for recycling of synaptic vesicle membrane during transmitter release at the frog neuromuscular junction. $J$. Cell Biol., 57, 315-344.

3) Kadota, K. \& Kadota, T. (1978) Detection of depolarization-induced coated vesicles within presynaptic terminals in cat sympathetic ganglia maintained under a low temperature. Brain Res., 151, 201-205. 